\title{
Improvement of traditional processing of local monkey orange (Strychnos spp.) fruits to enhance nutrition security in Zimbabwe
}

\author{
Ruth T. Ngadze ${ }^{1,2} \cdot$ Ruud Verkerk $^{2}$ • Loveness K. Nyanga ${ }^{3}$ • Vincenzo Fogliano ${ }^{2}$. \\ Anita R. Linnemann ${ }^{2}$
}

Received: 9 February 2016 / Accepted: 31 March 2017 / Published online: 18 May 2017

(C) The Author(s) 2017. This article is an open access publication

\begin{abstract}
Although the monkey orange (Strychnos spp.) tree fruit is widely distributed in Southern Africa and particularly in Zimbabwe, it is underutilized and little attention has been given to its potential commercialisation due to limited knowledge and information. Most of the fruits and their products are wasted because of limited harvest time, process control and storage conditions, leading to variability in shelf life and sensory quality, thereby impacting nutritional quality. Traditional processing techniques make insufficient use of this food resource within rural communities. This study aimed at identifying the existing bottlenecks by means of a survey among 102 smallholder farming respondents in the wet and dry regions of Zimbabwe. Results revealed that $S$. cocculoides and S. spinosa were used by $48 \%$ of respondents as a functional ingredient in porridge, by $25 \%$ in fermented mahewu drink and by $15 \%$ of respondents as a non-alcoholic juice. The fruits of $S$. innocua and $S$. madagascariensis are preferably processed into dried products. Taste, flavour and colour were the important quality characteristics for all processed products, and constraints to be solved are seed-flesh separation, long processing times, separation of juice and pulp during storage as well as pulp viscosity. Respondents reported monkey orange products to have health benefits for children and immune-compromised people, who, on regular consumption,
\end{abstract}

Anita R. Linnemann

anita.linnemann@wur.nl

1 Department of Food Science and Technology, Chinhoyi University of Technology, Chinhoyi, Zimbabwe

2 Food Quality and Design, Wageningen University and Research, Wageningen, The Netherlands

3 Institute of Food, Nutritional and Family Sciences, University of Zimbabwe, Harare, Zimbabwe have reportedly increased weight and resistance to disease. The positive perception about the processed products of Strychnos spp. offer a good opportunity to improve nutrition security by capitalizing on these not-yet-fully-exploited resources, but technological solutions to improve sensory quality and shelf life must be developed.

Keywords Traditional processing $\cdot$ Monkey orange $\cdot$ Strychnos cocculoides $\cdot$ Strychnos spinosa $\cdot$ Strychnos innocua $\cdot$ Strychnos madagascariensis

\section{Introduction}

Indigenous fruit trees in Africa supplement the diet of many rural families by providing essential nutrients (Bille et al. 2013; Nhukarume et al. 2010) and serve as a livelihood source, especially in times of famine (Legwaila et al. 2011; Mithöfer and Waibel 2003; Packham 1993). Hundreds of indigenous fruit species exist in Africa that are locally significant, although they might be unknown in global markets (Jamnadass et al. 2011). These locally important species are, however, frequently underutilised, leading to erosion of their usefulness and restricting development options for poor communities (Ekué et al. 2010). Some studies have been conducted to assess knowledge by local communities in Zimbabwe on processed products of indigenous edible fruits such as beverages derived from sand apple (Parinari curatellifolia), marula (Sclerocarya caffra) (Gadaga et al. 1999), baobab (Adansonia digitata) (Mpofu et al. 2014), and ber (Ziziphus mauritiana) (Nyanga et al. 2008).

Strychnos spp. (monkey orange) have been identified among the top priority fruit species in Southern Africa through ethnobotanical surveys (Mkonda et al. 2002; Saka et al. 2004), particularly in dry areas of Zimbabwe such as Binga (Mpofu 
et al. 2014). This fruit tree proliferates in areas with a prolonged dry season, remains dormant when water is unavailable and bears fruit in abundance (Mwamba 2006; National Research Council 2008). The excess production of the fruit leads to its underutilization and this can be seen in the veld around Zimbabwe where fruit remains littered and unpicked when in season. Five common Strychnos species grow wildly across the agro-ecological regions of the country, with wide distribution patterns. $S$. cocculoides is found in the north, west, central and south, S. spinosa in the north, west, central, east and south, S. innocua in the north, central, east, and south, S. madagascariensis in the north, west, central, east and south, and $S$. pungens in the north, west and central parts of Zimbabwe (Mapaura and Timberlake 2004; Van Wyk and Van Wyk 1997). Though the Strychnos spp. fruit is widely distributed in Zimbabwe, it is underutilized and little attention has been given to its potential commercialisation due to limited knowledge and dissemination of information about propagation, agronomic practices and product processing techniques.

Strychnos spp. fruits ripen and are harvested from September to December (Akinnifesi et al. 2007), a time when intense agricultural labour coincides with low maize stocks and the unavailability of freshly-gathered vegetables (McGregor 1995). The season of prolonged food scarcity often increases reliance on consumption of indigenous fruits by the entire family (Shackleton et al. 2000). In addition to the consumption of fresh fruit, traditional fruit processing is most common in drier climatic areas for the supplementation of food requirements (Saka et al. 2004). An estimated $46 \%$ of rural households have reported processing indigenous fruit into juices and/or porridges (Kalaba et al. 2009), along with several other food products that can be used as a complement and substitute for the local cereal-based staple foods.

Strychnos spp. has been identified to contribute more than $100 \%$ of the recommended daily intake for vitamin $\mathrm{C}, \mathrm{Fe}$ and $\mathrm{Zn}$; especially for children between four and eight years old and for pregnant women (Ngadze et al. 2016). Gadaga et al. (2009) noted that over $65 \%$ of Zimbabweans live in rural areas and are food insecure, especially during prolonged dry periods, while malnutrition problems through vitamin and mineral deficiencies have public health significance in the country. Because of their wide availability and nutritional composition, monkey oranges have potential for contributing to the alleviation of vitamin and micronutrient deficiencies of the vulnerable rural population, particularly children and women, by complementing the monotonous staple food diet. In Zimbabwe, extension services of government and Non-Government Organizations (NGO's) are a bridge for the transfer of information on the contribution of indigenous fruit species to health and nutrition to the end user, through training of women groups and cooperatives in new processing possibilities.
To date, indigenous knowledge on the collection and processing of Strychnos spp. products in Zimbabwe has received limited attention. Usually indigenous fruits are considered to be a "poor man's food" or famine food. Erosion of cultural norms through urbanization and increased cultivation of exotic fruits and their marketing have led to further reduction of the use of indigenous fruits. The lack of awareness of the potential health benefits and standardized processing of these fruits keep them away from most diets and adversely affect the utilization of the fruits and nutrition security.

Thus, our present study aimed to assess and document specific traditional processing techniques and their bottlenecks in identified rural communities and regions in Zimbabwe with the objective of determining which food technological improvements would support the role of indigenous monkey orange fruits as a way to improve nutrition security. Strychnos spp. has the potential to generate income for actors in the value chain within local and regional markets, as in the case of baobab fruit and other African indigenous fruits that reportedly reduce poverty by $33 \%$ during the critical period of the year (Chadare et al. 2008; Mithöfer and Waibel 2003). Aspects explored in our study include processed products, processing steps, constraints and consumption patterns of the fresh fruits and their products. The study also provides information on local food uses of Strychnos species, which is important for further research on the implications of processing and storage for nutritional health benefits and sensory quality.

\section{Methodology}

\section{Study area and sample size}

The study areas (Fig. 1) were chosen on the basis of the abundance of Strychnos spp. fruits, in wet and dry regions of Zimbabwe. For exhaustive data collection on the different species, areas that cover the five agro ecological regions of Zimbabwe (Vincent et al. 1961) were chosen carefully using information gathered initially with assistance from NGO extension services on the basis of community utilization of Strychnos spp. The objective of this research was primarily based on indigenous knowledge, where a limited number of people served as primary data sources. Thus, holders of information about indigenous fruit processing and about village chiefs were identified and purposively selected on account of their experience and past participation in other surveys. Villages were visited prior to the survey for familiarization with the community. Consent from the village chief was obtained after clear demonstration of research intentions and protocols. Monkey oranges are underutilized, not commercialised and commonly consumed and processed locally in rural homesteads. Thus, often the actors that process the 


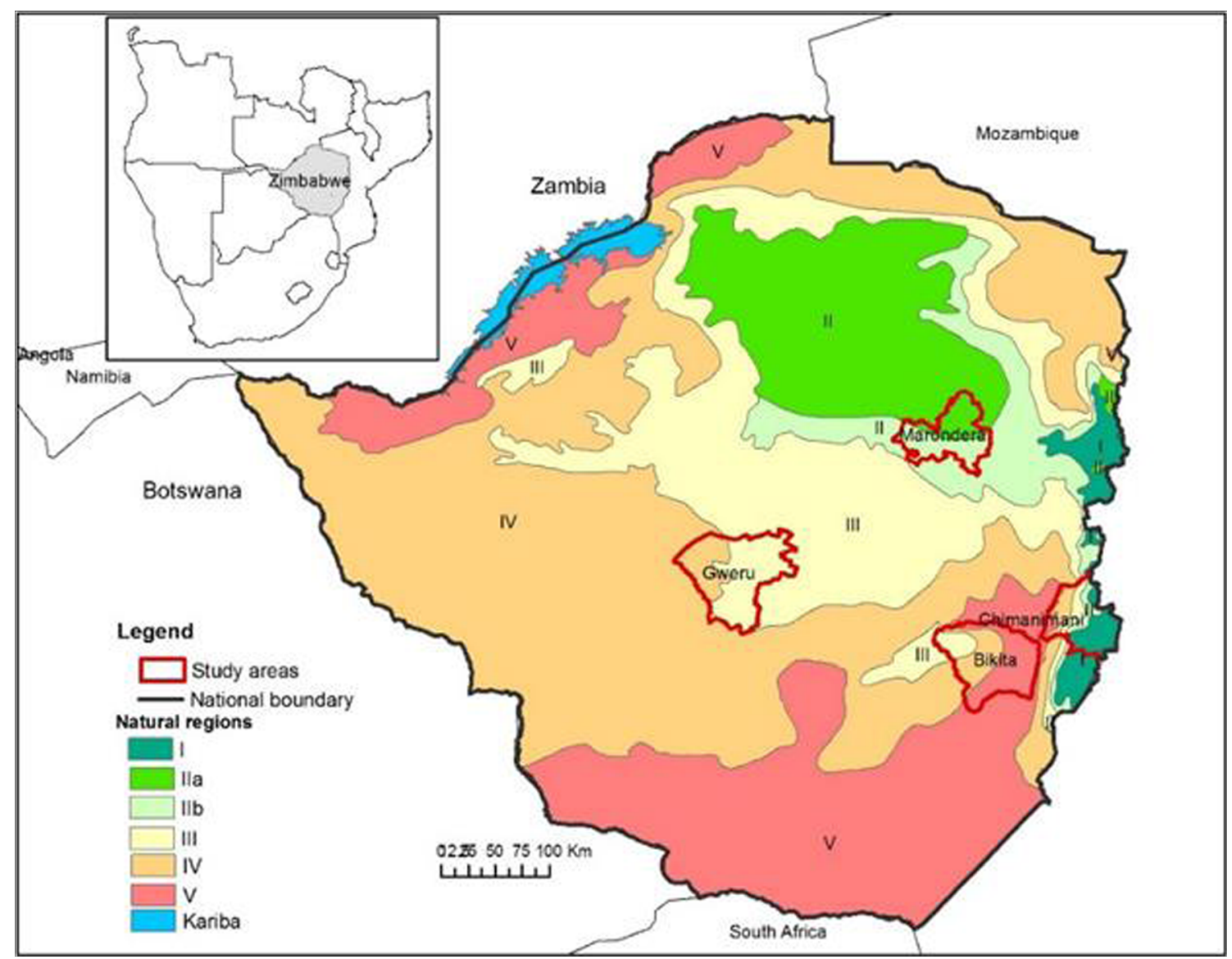

Fig. 1 Study areas surveyed for indigenous knowledge of Strychnos spp. V < 450), namely Gweru (region III and IV), Marondera (region II), fruit collection and product processing in Zimbabwe (annual rainfall Chimanimani (region I, II and III) and Bikita (region II, IV and V) region $I>1000 \mathrm{~mm}$, II 750-1000, III 650-800, IV 450-650 and region

fruits are concealed leading to the 'snowballing method' as the best method to uncover that population. According to Katz (2006), "Snowball sampling is a special nonprobability method for developing a research sample where existing study subjects recruit future subjects from among their acquaintances and where a sampling frame is hard to establish". Though snowballing is not statistically representative, the sampling technique is suitable when the human populations being surveyed are difficult to pinpoint and locate because of their limited numbers. Village chiefs, elders and leaders of women's groups suggested the initial participants for the survey, then the identified respondents suggested other households, where selection was based on their knowledge of processing Strychnos spp. Informed consent was obtained from all individuals in each participating household in this study. With an estimated average size of 150 inhabitants per village, at least five \% of the population of the village were interviewed as a representative sample (Mpofu et al. 2014). A total of 102 respondents were interviewed, where 20-40 informants were recruited in each community.

\section{Data collection}

Data were obtained during field visits using questionnaires administered through face-to-face interviews, in detailed focus group discussions and by observations during the monkey orange season from September through December 2014. Observations during the harvesting and processing of monkey oranges were made as follow-ups to the information obtained from the respondents. The interviews were either with individuals or in group discussions in the local Shona and Ndebele languages (with the assistance of local translators), which were well understood by all respondents, so as to obtain indepth information. Detailed discussions were used to generate data from groups of between 10 and 15 participants in selected communities. A relevant leader of the community, who was believed to have more experience and in-depth knowledge of the fruit and area, was identified for each focus group. The focus group dynamics facilitated the generation of forgotten information. Ages of respondents ranged from 20 to above 70 years. In each locality, information was gathered by answering questions based on the following parameters: (1) fruit harvesting and gathering, (2) processing methods, (3) 
consumption patterns, (4) storage practices of fruit and fruit products, and (5) processing and storage constraints. Specific questions were developed for each actor and were subdivided as follows:

- At the collector's level: Fruit species, collection period, distance covered for fruit collection, fruit quality characteristics (colour, taste, maturity and size), method of collection, fruit storage and ripening, collection constraints, customers for fruits, selling price, end uses of fruit.

- At the processor level: Processed products, quality of processed products (colour, taste, odour), frequency of processing, end consumer (household use or trade), quantity and price of products and customer preferences.

- At the consumer level: Procurement of product, quality characteristics, storage of product, consumption time and quantities, quality perception of consumed product (colour, taste, odour), further processing including the use of product as an ingredient.

Focus group discussions were centred on obtaining information about harvesting methods, product processing and quality constraints, processing steps and the uses of product as an ingredient. Observations during the harvesting and processing steps were conducted as a follow up to the information obtained from the farming respondents.

\section{Data analysis}

The data were analysed using SPSS 22.0 for Windows (Apache Software Foundation, USA) and Microsoft Excel 2013. Data were subjected to descriptive statistics from coded questions asked in the individual interviews.

\section{Results and discussion}

\section{Gathering and selection of monkey orange fruits and food products}

Figure 2 shows photographs of the pulp of fruits from three Strychnos species found in Zimbabwe. Data collection for

Fig. 2 Pulp of a Strychnos spinosa, b Strychnos cocculoides and c Strychnos innocua fruits of the same species may be imprecise (Termote et al. 2010). "Under-differentiation" of a species is encountered when a single vernacular name can be used for species of morphological similarity, or "over-differentiation" when several names are used for one species (Rampedi and Olivier 2013). Thus, to gather reliable and reproducible information, the species were grouped into two major groups: group A (comprising $S$. cocculoides and $S$. spinosa) and group B (S. innocua and S. madagascariensis). Within either group, the species' phenotypic and sensory characteristics are similar and hence traditionally similar vernacular names are used (Table 2).

In all the areas visited, Strychnos spp. are harvested from September to December, i.e. the warm summer period marking the end of the dry season and the beginning of the rainy season. Citation of fruit species in the localities we visited is illustrated in Table 2. The most frequently cited species in Lower Gwelo and Marondera were S. cocculoides and S. spinosa, while Bikita and Chimanimani respondents cited mainly $S$. innocua and $S$. madagascariensis. S. pungens is not included in the description of the processing results because respondents did not process fruits of this species due to its limited availability. Each informant cited on average three species known to them and identified two species found in their locality.

Gathering and fruit selection are principally activities conducted by women during their daily chores when they tend the field or collect firewood, and by children going to and from school or as they herd cattle. Females made up the majority of the respondents (83\%) (Table 1). Females are usually identified as the majority of respondents in studies such as ours because they are regarded as the custodians of traditional knowledge (Dovie et al. 2008) (Table 2).

In this study we found that Strychnos spp. trees were often confined to another individual's homestead or field and respondents freely collect the fruits without seeking authority since monkey orange trees and fruits continue to be regarded as communally-owned in all areas visited. Because the fruits are found within walking distance from homesteads and are communally owned, they are accessible and free to harvest, and available in times of seasonal imbalances, especially for the rural poor. In Zimbabwe, indigenous fruit trees are
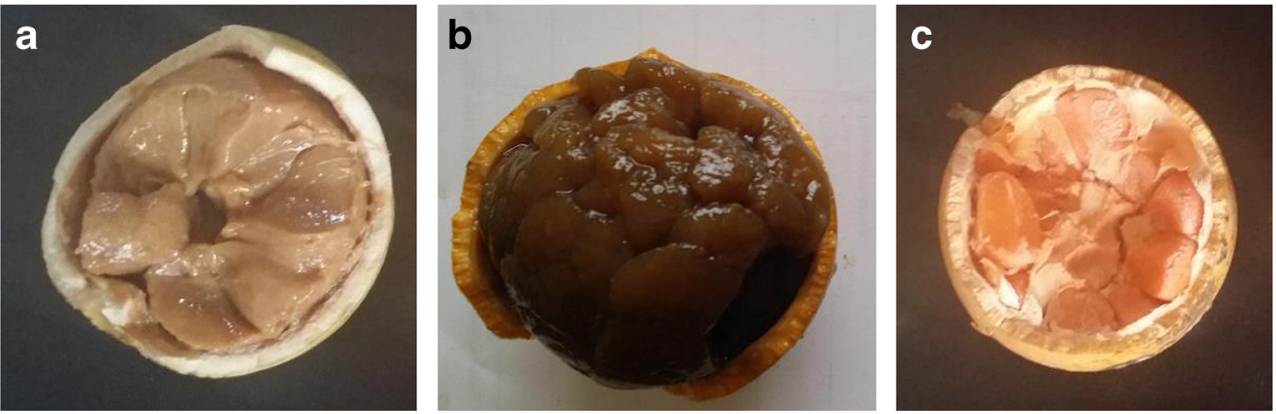
Table 1 Demographic profile of respondents in the districts visited during a survey for indigenous knowledge of Strychnos spp. fruit collection and product processing in Zimbabwe

\begin{tabular}{|c|c|c|c|c|c|c|c|c|c|}
\hline \multirow[t]{2}{*}{ Region } & \multirow[t]{2}{*}{ District } & \multirow[t]{2}{*}{$\mathrm{N}$} & \multicolumn{2}{|l|}{ Gender } & \multicolumn{5}{|c|}{ Age } \\
\hline & & & Female & Male & 20 & $21-35$ & $36-50$ & $51-70$ & Above 70 \\
\hline \multirow[t]{2}{*}{ Wet-semi wet region } & Chimanimani (Region I and II) & 20 & 16 & 4 & 6 & 1 & 7 & 3 & 3 \\
\hline & Marondera (Region II) & 40 & 32 & 8 & 1 & 5 & 13 & 14 & 7 \\
\hline \multirow[t]{3}{*}{ Dry region } & Lower Gwelo (Region IV and V) & 22 & 18 & 4 & 0 & 2 & 9 & 7 & 4 \\
\hline & Bikita (Region III, IV and V) & 20 & 19 & 1 & 0 & 6 & 8 & 5 & 1 \\
\hline & Total & 102 & 85 & 17 & 7 & 14 & 37 & 29 & 15 \\
\hline
\end{tabular}

generally located in forests, cropped fields, grazing parks and around homesteads (Akinnifesi et al. 2002).

The fruits are harvested by picking fallen fruits, or by climbing trees and plucking fruit from branches. Other harvesting practices such as shaking trees, or hitting them with stones or tree branches are also used. These modes of harvesting may cause damage to the hard shell of the fruit, which is a protective barrier to insect infestation and microbial contamination, thus potentially causing loss of sensory, nutritional and physical properties of the fruit.

For all species, major attributes for fruit maturity and harvesting were colour (89\% of respondents), liquefaction (72\%) and taste (49\%). Fruit colour changes from green to bright yellow or orange (colour intensity depending on species) at the onset of ripening. Specifically, for $S$. cocculoides and $S$. spinosa liquefaction is a common maturity indicator used by respondents, identified by holding the fruit to the ear and shaking to listen for the sound of sloshing pulp and loose seeds. The best tasting fruits are known from past experience and respondents know the location of the trees that bear the most delicious fruits. These results concur with those of Akinnifesi et al. (2007), where they concluded that traditionally in Southern Africa the harvesting of indigenous fruits depends largely on past knowledge and observations within the community.

We noted that in all areas there is variation in taste between species and within species, from bitter, astringent to sweet. Taste and flesh consistency are also used to distinguish between species' groups. S. cocculoides and S. spinosa were described as sweet or sweet and sour, with a brown juicy flesh when ripe. The sweet taste of fruit from $S$. cocculoides explains why it is the most preferred of the monkey orange species (Mwamba 2006). Citric, malic and succinic acids found in $S$. spinosa species may contribute to the sourness perceived by consumers. S. madagascariensis and $S$. innocua fruits were described as containing bright yellow firm flesh, with a sweet to bitter taste, which has been attributed to the presence of tannins in S. innocua flesh (Bello et al. 2008). Fruit colour, liquefaction and taste superseded other collection and selection criteria such as fruit size $(21 \%)$ and weight (17\%).

\section{Fruit storage practices and constraints}

Of the four monkey orange species, $S$. cocculoides was the only species that was picked unripe and stored for ripening;

Table 2 Inventory of Strychnos spp. identified and collected in Zimbabwe

\begin{tabular}{|c|c|c|c|c|c|c|c|}
\hline \multirow{3}{*}{$\begin{array}{l}\text { Species } \\
\text { group }\end{array}$} & \multirow{3}{*}{$\begin{array}{l}\text { Vernacular name } \\
\text { (Shona) }\end{array}$} & \multirow[t]{3}{*}{ Common name } & \multirow[t]{3}{*}{ Botanical name } & \multicolumn{4}{|c|}{ Citation in locality (\%) } \\
\hline & & & & \multicolumn{2}{|l|}{ Wet region } & \multicolumn{2}{|c|}{ Dry region } \\
\hline & & & & Chimanimani & Marondera & $\begin{array}{l}\text { Lower } \\
\text { Gwelo }\end{array}$ & Bikita \\
\hline \multirow[t]{2}{*}{ A } & $\begin{array}{l}\text { Matamba } \\
\text { Mazhumwi }\end{array}$ & $\begin{array}{l}\text { Corky-bark monkey } \\
\text { orange }\end{array}$ & Strychnos cocculoides & 55 & 95 & 96 & 50 \\
\hline & $\begin{array}{l}\text { Matamba } \\
\text { Mun'ono }\end{array}$ & $\begin{array}{l}\text { Spine-leaved monkey } \\
\text { orange }\end{array}$ & Strychnos spinosa & 30 & 93 & 64 & 65 \\
\hline \multirow[t]{3}{*}{ B } & $\begin{array}{l}\text { Hwakwa } \\
\text { Makwakwa } \\
\text { Mudo }\end{array}$ & Dull-leaf monkey orange & Strychnos innocua & 100 & 28 & 36 & 100 \\
\hline & $\begin{array}{l}\text { Hwakwa } \\
\text { Makwakwa }\end{array}$ & $\begin{array}{l}\text { Hairy-leaved monkey } \\
\text { orange }\end{array}$ & $\begin{array}{l}\text { Strychnos } \\
\quad \text { madagascariensis }\end{array}$ & 100 & N/A & N/A & 100 \\
\hline & Mutamba-usiku & Green monkey orange & Strychnos pungens & 5 & 48 & N/A & 100 \\
\hline
\end{tabular}


the other three species were only picked when ripe. In total, from all the regions surveyed for $S$. cocculoides, $89 \%$ percent of the respondents picked fallen ripe fruits, and $70 \%$ picked mature fruits from the tree. Twenty seven percent of respondents picked light green mature fruit for ripening during storage. According to respondents, the degree of maturity was not a constraint as through experience they know the ideal stage of maturity that allows the fruit to ripen in storage. Because of their hard shell and acidic nature with a $\mathrm{pH}$ of around 3.5 (Saka et al. 2007), Strychnos spp. can tolerate relatively high temperatures and long storage times before deteriorating in quality. Ripening could be either accelerated or reduced by different storage methods. Methods used to accelerate ripening are the mimicking of dark, air tight conditions, such as by burying fruits underground in sand, in sacks with dry hay, dry chicken manure, mealie meal or fine wood ash. Thus, the fruits are kept in the buried environments in order to control the atmospheric conditions that allow the concentration of the ethylene plant hormone that consequently hastens the ripening period, signifying the climacteric nature of the fruit (Barry and Giovannoni 2007; Sitrit et al. 2003). Respondents indicated the storage treatment and estimated the storage time of the fruit based on their experience. They indicated that picking of mature unripe fruits for storage in burial places also reduces competition from other fruit collectors, especially of a wellknown, sweet tasting variety, which is in line with findings of Motlhanka et al. (2008) and Rampedi and Olivier (2013). Unripe mature fruits can be stored in this manner for more than two months (according to $18 \%$ of the respondents). To delay ripening, mature fruits are kept cool by storing them in ventilated grain sacks, under (or in) granaries and in closed clay pots. Ripe fruits can be stored for one month $(59 \%$ of the respondents), two months ( $9 \%$ of respondents) and more than two months ( $1 \%$ of respondents), before they rot. Thirty percent of respondents said they immediately consumed or processed the fruit and did not store the fruit at any stage of collection. The constraints identified by the respondents were a shortage of fruits of the sweet tasting variety, and seasonality, where respondents desired a longer storage time and extended availability of fruits throughout the year.

\section{Indigenous processing knowledge}

According to our survey, fruits of Strychnos spp. are harvested for a period of between three and four months and in excess of what is consumable during the harvest season; and thus some fruits are processed. Strychnos spp. products were broadly classified as products for either future use or immediate use, for the purposes of this survey. For all processed products of Strychnos spp. the first step was to wash fruits with clean water to remove dirt and dust particles. The flesh is exposed by pounding and cracking the shell on a hard surface or with a stone, after which specific processing is done. An outline of the processing methods used is shown in Fig. 3 and details of the processing of each product are given in the following sections.

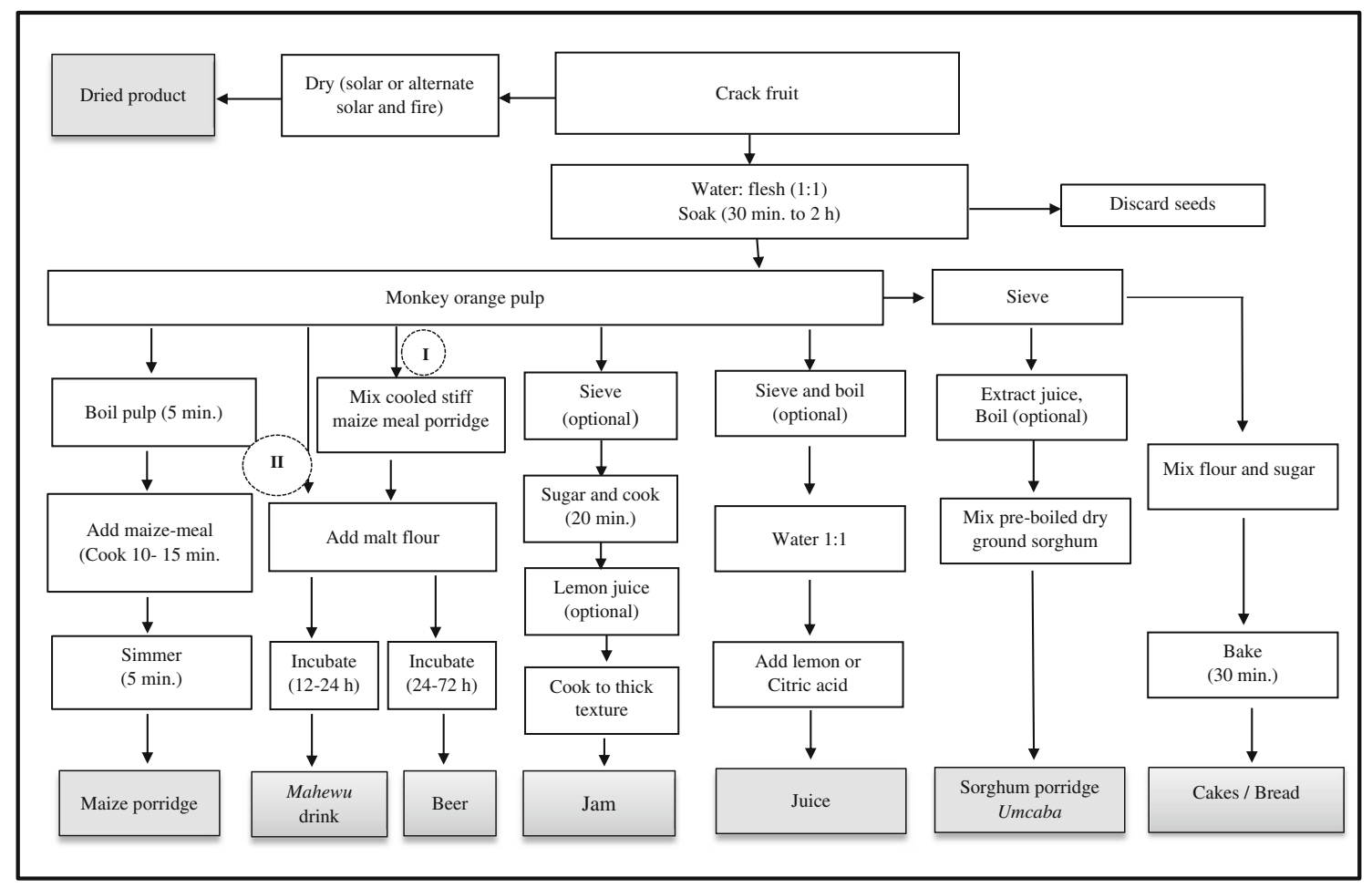

Fig. 3 Overview of processing methods of Strychnos spp. fruit in Zimbabwe 


\section{Food products for prolonged storage}

Drying of S. innocua and $S$. madagascariensis In Bikita district, high temperatures and low rainfall often result in poor harvests of staple food crops and fresh vegetables. This has led to reliance on the processing of indigenous fruit, particularly drying of S. innocua and S. madagascariensis (typical to dry regions in Zimbabwe such as Bikita), so as to reduce fruit moisture content for prolonged preservation. All respondents in Bikita district use alternate sun and fire drying due to a lack of electricity for refrigeration and mechanized equipment. The alternate use of the two drying methods was done primarily to reduce drying time as the sugar content of $S$. innocua necessitates prolonged drying. In contrast, there was no drying practised with the species in Chimanimani district, a wetter area in Zimbabwe. It was observed that though abundant in Chimanimani district during the fruiting season, S. innocua and S. madagascariensis fruits were heavily littered, indicating underutilization even for consumption as fresh fruits. This was attributed to the fact that the region's high rainfall and fertile soils are appropriate for other agricultural cropping practices, and hence other food sources are available and affordable.

Prior to drying, fruit flesh is pre-treated with either fine salt, crystalline sugar or both, depending on consumer preference. The flesh/seed is spread and pressed to stick to the surface of hand-plaited reeds interlocked with strips of palm leaves. By midmorning, the rack is exposed to the sun on a traditional dish rack (called dara) or on bundles of firewood. The rack's position is changed throughout the day for maximum exposure to the sun. At dawn of the following day, the rack is firedried with wood as the fire source, or (when wood is unavailable) corn cobs or stalks (Fig. 4). Fire drying is done for at least four hours, and thereafter the product is left uncovered on the kitchen floor overnight. A layer of fresh fruit flesh is added the next morning and the consecutive sun and fire drying steps follow as the previous day. The alternate sun and fire drying steps are continued for five to seven consecutive days, where the length of processing depends on the desired thickness of product, household size and consumer preference. The product obtained can be stored for more than three months according to $75 \%$ of respondents, while $25 \%$ of respondents said they consumed the product soon after processing and did not store for later consumption. Most consumers of the product said they had a sensory preference for the smoky flavour of the product. Wood smoke and fire-charred wood produce chemical components such as lactones, alcohols, carbonyls, esters, furans, and phenols, which exhibit several flavours, including pungent, bitter, spicy, burnt sugary, or smoky flavours (Maga 1987). Without the smoky flavour the product was reported as not well accepted by consumers.

Sun drying of S. cocculoides and S. spinosa Solar drying of $S$. cocculoides and S. spinosa was commonly done in Lower Gwelo (68\%) district. During hot summer days, monkey orange flesh is either spread over a flat surface with maximum heat absorbance or in traditionally-made solar driers covered with transparent or black plastic. The solar dryers use convective air for heat that subsequently dries the product. Drying takes between five days and two weeks, depending on prevailing weather conditions and whether the desired moisture content is reached. The determination of the moisture content is subjective, and physical tests, such as stickiness of the product, are reported often to be used to evaluate if the product is dry enough. When dried sufficiently, the product is stored at room temperature in perforated sacks. The dried product is the starting material to prepare sweet and snack products or for inclusion as an ingredient in different preparations such as juice, porridge or beverages.

\section{Food products for immediate consumption}

S. cocculoides and $S$. spinosa pulp is combined with other ingredients to make porridge, alcoholic and non- alcoholic beverages and, less frequently, jam and confectionary for immediate consumption as in Table 3. Immediate consumption in this context implies consumption from the time of processing until no more than two to three days later.
Fig. 4 Drying process of S. innocua and S. madagascariensis in Bikita district, Zimbabwe

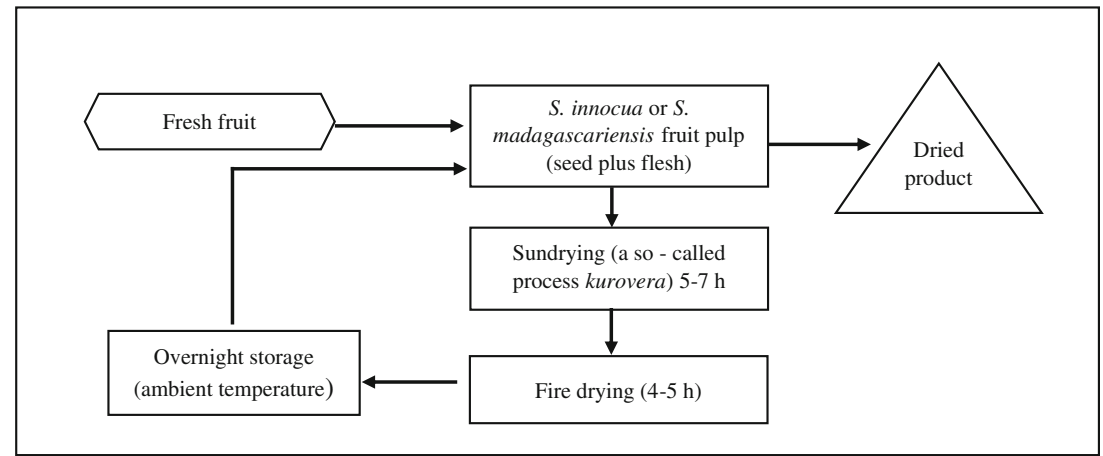


Table 3 Meal times of specific monkey orange-based products in study regions

\begin{tabular}{llllll}
\hline \multirow{2}{*}{ Species } & \multirow{2}{*}{ Product } & \multicolumn{2}{l}{ Meal times $^{\mathrm{a}}(\mathrm{N})$} & \\
\cline { 3 - 6 } & & Breakfast & Lunch & Between meals & Supper \\
\hline S. innocua and S. madagascariensis & Dried & 3 & 5 & 17 & 0 \\
S. cocculoides and S. spinosa & Porridge & 49 & 1 & 2 & 0 \\
& Dried & 1 & 4 & 13 & 0 \\
& Juice & 1 & 4 & 10 & 0 \\
& Mahewu & 2 & 6 & 16 & 0 \\
& Beer & 0 & 1 & 5 & 0 \\
\hline
\end{tabular}

${ }^{a}$ Respondents answered to meal times for all the products consumed in the household, where each respondent may have answered consumption times for more than one product
Porridge Two variations of cereal-based porridge meals made with $S$. cocculoides or S. spinosa (group A) pulp were encountered in the survey. The first porridge variant was a maizebased porridge (called mutandabota) prepared in $15 \%$ of the households in Bikita, $30 \%$ of those in Chimanimani, $55 \%$ in Marondera and $82 \%$ of households in Lower Gwelo. Maize porridge is the most commonly processed product using group A spp. The second porridge variant was a sorghum-based porridge (called umcaba), as identified by a focus group in Lower Gwelo area.

For the maize-based porridge, pulp is macerated in water for $30 \mathrm{~min}$. to $2 \mathrm{~h}$, either standing or with whisking using a wooden spoon to detach flesh material from the seeds. The resulting juice or pulp is subjected to heat, and upon boiling, white maize meal (Zea mays) to water 1:4 $(w / v)$ is added with stirring until a lump free, gelatinized and a uniform slurry is obtained; the maize-based porridge. For the sorghum-based variant, untreated monkey orange pulp or juice is mixed with boiled, solar-dried ground sorghum, and then consumed immediately. In both processing methods, the porridge products are generally thin, flavoured with peanut butter or sweetened with crystalline sugar. Texture of the maize meal variant depends on the weight to volume ratio of maize meal flour to monkey orange pulp. The maize porridge is usually consumed immediately while slightly hot or warm as a breakfast food or snack. It can also be stored in closed clay pots and in cool conditions for a maximum of two days for re-warming prior to consumption.

Fermented beverage Thirty five percent of the households interviewed in Marondera and $41 \%$ of respondents in Lower Gwelo fermented $S$. cocculoides and S. spinosa pulp to make mahewu, a sweet sour cereal-based fermented non-alcoholic beverage containing fresh monkey orange pulp. Two variations were encountered in the preparation of a fermented beverage. In processing method I, the pulp was mashed with cool stiff maize meal porridge ( $s a d z a$ ) (Fig. 3). Either maize, sorghum or millet flour was added to the mashed product as the fermentation substrate. In processing method II (Fig. 3), sorghum or millet flour was added to the fruit pulp without mashed stiff maize porridge as an initial ingredient. For either variant, the resultant mixture is incubated for $12-24 \mathrm{~h}$ to facilitate fermentation at ambient temperatures and both are referred to as mahewu. Saccharomyces yeasts, inherent to the cereals, contribute to flavour development of mahewu (Blandino et al. 2003).

Respondents in Marondera (10\%) and Lower Gwelo (14\%) added yeast and prolonged the fermentation time to produce an alcoholic brewed beer. When an alcoholic beverage is to be prepared, yeast is added to the product of process I, set near a cooking fire (to maintain temperatures above $30{ }^{\circ} \mathrm{C}$ ) and allowed to ferment naturally over a period of three to four days.

Unfermented beverage The whole fruit pulp or sieved monkey orange juice may be used to prepare juice. Pulp is sieved or strained with a mesh sieve substituted traditionally with a woven high-density polyethylene (HDPE) fruit sack. Water is added in a 1:1 ratio and lemon fruit juice or citric acid (depending on availability) is added as a preservative for the juice. The juice is boiled and crystalline sugar added, again depending on consumer preference and intended storage time. The product was consumed within three days. This type of juice was prepared by $5 \%$ of the households in Chimanimani, $15 \%$ in Marondera and $41 \%$ in Lower Gwelo.

\section{Product consumption}

Monkey orange products and their consumption patterns among respondents are shown in Table 3. Dried S. innocua and $S$. cocculoides were mainly consumed as a sweet snack at lunch time or between meals during time of chores by women and children. Fermented beverage (mahewu) was consumed fresh, though some respondents stored the product for a maximum of two days in a cool environment. Beer was consumed fresh and up to two to three days after preparation as a leisure drink during traditional ceremonies and social gatherings. 


\section{General utilization}

In the dry region, consumption of monkey orange fruits was $100 \%$ for group B spp. and 74\% for group A spp. In the wet region consumption was $82 \%$ for group $\mathrm{A}$. The high values obtained were because the fruit was consumed in its unprocessed fresh state, hence the high general use for both groups of species as a pulp. Fruits from the species groups were used to process the same products, though $S$. innocua and S. madagascariensis fruits were not used as a dried product in the wet region. The proportion in which a particular product was used only significantly varied $(p<0.05)$ between the two regions for both groups of species for the dried product of group A and for fresh pulp of group B (Fig. 5).

There was a marked difference in uses between the two groups of Strychnos spp. Group A species had more uses and were processed into more products than group B species in both regions. Uses for group B species was higher in the dry region than in the wet region. Respondents from the wet region only consumed the fresh fruit of $S$. innocua or S. madagascariensis. These findings and observations suggest that the poorest of the resource limited communities (in the dry region) better utilize their indigenous fruit by processing than rural communities that are better off. Communities, however, do not have proper preservation techniques to allow for long term use and storage when fruits are out of season, leading to loss of product by rotting and underutilization.

We found in this study that, in addition of their food value, monkey orange fruits and products are marketable. In general, selling was done in the drier and poorer regions, indicating the possibility of supplementing income in these marginal areas. Dried S. innocua or S. madagascariensis was mainly sold informally at rural growth points (small business centres in rural communities where basic essential services and markets are concentrated) and from home-to-home. A stack of dried fruits about $100 \mathrm{~g}$ in weight was sold for US \$1 with its price doubling as the fruit drew out of season. Juice was sold at US $\$ 1$ for $750 \mathrm{ml}$ at gatherings. None of the products was reportedly sold in the formal markets at the time of the survey, demonstrating underutilization of monkey orange despite its potential for trade as has been indicated in other studies where monkey oranges are traded between Southern African countries (Mkonda et al. 2002; Ruffo et al. 2002; Southampton Centre for Underutilised Crops 2006). Women, being the custodians of neglected and underutilized fruits, may be empowered by a change in this situation.

\section{Product processing constraints and quality criteria}

Figure 6 presents an overview of processing operations, constraints and sensory quality characteristics of products from Strychnos spp. in the study areas.

Solar drying of $S$. cocculoides and S. spinosa is highly dependent on environmental temperatures and conditions. Fruits are harvested in the rainy season, a period when drying conditions are indefinite, usually resulting in extended drying times and added demand for labour. The dried products are also highly hygroscopic, and require storage in dry conditions. To prevent the loss of quality by an ingress of moisture, the processed product was stored in plastic sacks or tins with tight closing lids and re-dried to extend its shelf life. The absence of efficient drying and storage facilities for monkey oranges was identified as a prominent difficulty, especially when the rainy season begins. These processing and quality constraints were highlighted as highly problematic in the focus group discussion. Other quality constraints observed during drying were dust, and animal and mould contamination, especially during humid weather. When solar driers were used, poor hygienic standards were also noted as a factor of equal importance through the inclusion of seeds and vegetables from previous drying processes. This may also account for the degradation of product quality.
Fig. 5 Processing frequency of Strychnos spp. among study regions

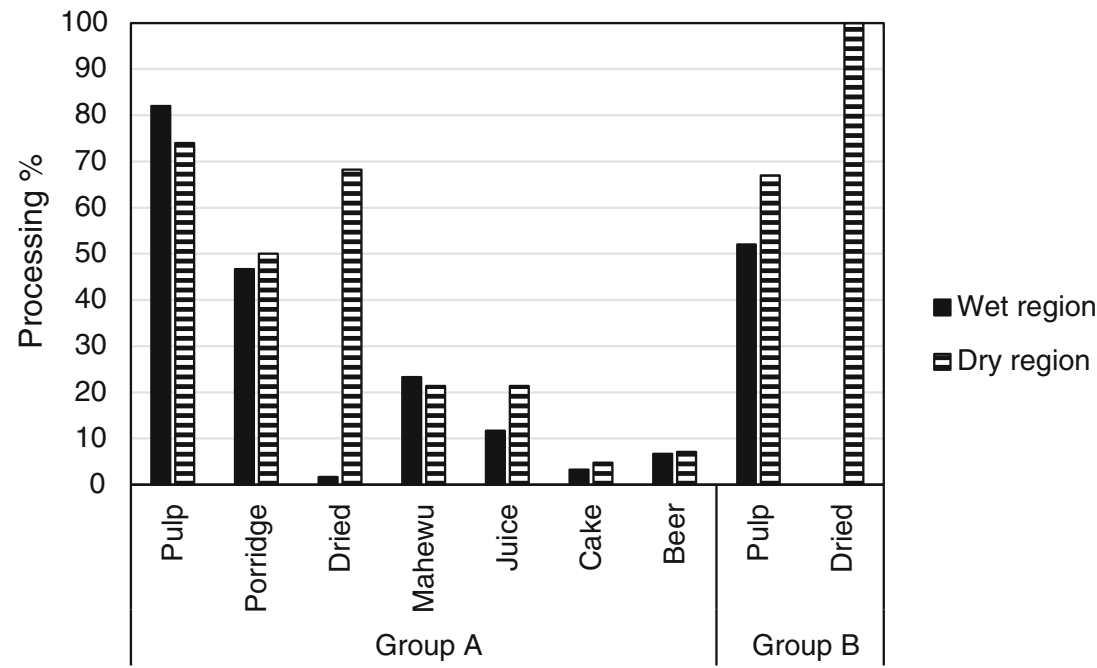


Fig. 6 Process constraints and quality criteria identified by respondents in study regions

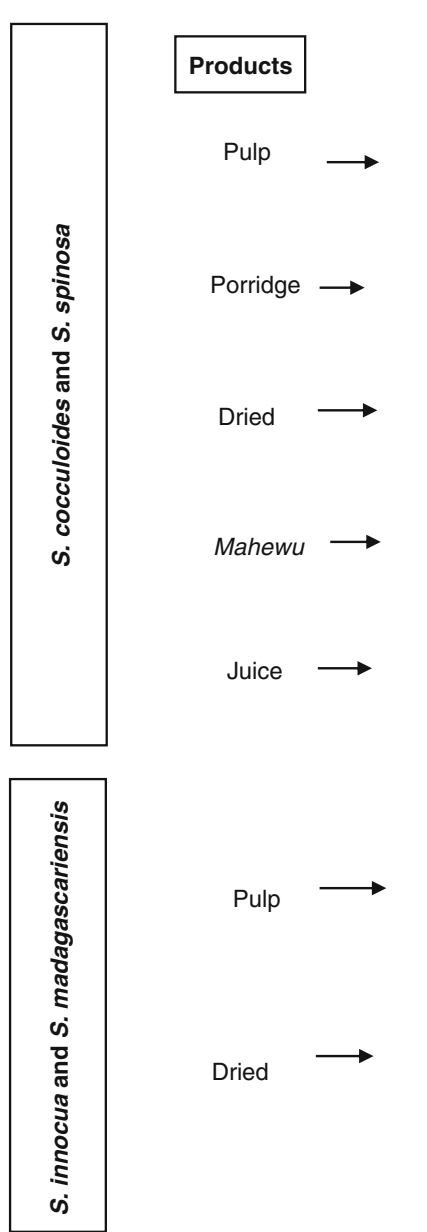

Important quality characteristics of dried $S$. innocua and S. madagascariensis product are colour, a smoky flavour and low moisture content, though they vary from one processor to another and from time to time. Respondents appreciated a golden to brown colour; a darker colour than this was perceived as charred and likely to have a characteristic burnt taste and flavour. Though fruit is spread uniformly on the drying rack, the desired colour is difficult to achieve due to variation in fire and solar temperatures because heat and air flow are not controlled or uniformly distributed on the drying rack during the drying period. Therefore processors have to continuously change the rack position during both fire and solar drying. Typical wood smoke flavour is caused by factors such as wood moisture content, air temperature, intermediate or stable volatile compounds and chemical reactions with other food components (Maga 1987). These are not controllable at a household level. The type of wood used in fire-drying is based on availability, therefore differences in sensory quality of the product are encountered. The fruit may be pre-treated with sugar or salt before drying. Respondents indicated that crystalline sugar facilitates rapid drying, prevents the compacting of the dried product on the rack and eases separation on handling and consumption, while salt maintains colour and

\begin{tabular}{|c|c|c|}
\hline $\begin{array}{c}\text { Processing and } \\
\text { quality } \\
\text { constraints }\end{array}$ & $\begin{array}{c}\text { Important } \\
\text { sensory } \\
\text { quality }\end{array}$ & $\begin{array}{l}\text { Perceived } \\
\text { health } \\
\text { properties }\end{array}$ \\
\hline $\mathrm{N} / \mathrm{A}$ & $\begin{array}{l}\text { Taste } \\
\text { Colour } \\
\text { Weight }\end{array}$ & $\begin{array}{l}\text { Increased weight, } \\
\text { stature resistance } \\
\text { to disease for } \\
\text { young and old }\end{array}$ \\
\hline $\begin{array}{l}\text { Seed - flesh } \\
\text { separation: } \\
\text { low juice } \\
\text { yield }\end{array}$ & $\begin{array}{l}\text { Flavour } \\
\text { Viscosity }\end{array}$ & $\begin{array}{l}\text { Increased weight, } \\
\text { stature resistance } \\
\text { to disease for } \\
\text { young and old }\end{array}$ \\
\hline $\begin{array}{l}\text { Slow drying rate } \\
\text { Labour intensive } \\
\text { Product stickiness }\end{array}$ & $\begin{array}{l}\text { Moisture } \\
\text { content }\end{array}$ & $\mathrm{N} / \mathrm{A}$ \\
\hline $\begin{array}{l}\text { Storage } \\
\text { Separation of } \\
\text { phases }\end{array}$ & $\begin{array}{l}\text { Flavour } \\
\text { Sourness }\end{array}$ & $\mathrm{N} / \mathrm{A}$ \\
\hline $\begin{array}{l}\text { Seed and flesh } \\
\text { separation: low } \\
\text { juice yield } \\
\text { Limited storage } \\
\text { Separation of } \\
\text { phases }\end{array}$ & $\begin{array}{l}\text { Viscosity } \\
\text { Cloudiness } \\
\text { Flavour }\end{array}$ & $\begin{array}{l}\text { Increased weight, } \\
\text { stature resistance } \\
\text { to disease for } \\
\text { young and old }\end{array}$ \\
\hline $\mathrm{N} / \mathrm{A}$ & $\begin{array}{l}\text { Taste } \\
\text { Colour } \\
\text { Weight }\end{array}$ & $\mathrm{N} / \mathrm{A}$ \\
\hline $\begin{array}{l}\text { Variable drying } \\
\text { conditions } \\
\text { Slow drying rate } \\
\text { Splitting of } \\
\text { product } \\
\text { Large inedible } \\
\text { portion }\end{array}$ & $\begin{array}{l}\text { Colour } \\
\text { Flavour } \\
\text { Moisture } \\
\text { content- case } \\
\text { hardening }\end{array}$ & $\mathrm{N} / \mathrm{A}$ \\
\hline
\end{tabular}

texture of the fruit. Pre-treatment with sugars (i.e. osmotic dehydration) has been used in the preservation of other fruit to hasten drying, reduce browning, increase retention of volatiles and reinforce a sweet taste (Osorio et al. 2007). In some cases in the areas visited, pre-treatment was immediately followed by sun drying with no incubation leading to the assumption that some of the pre-treatment effects may not reach the maximum due to limited exposure to the osmotic agents, i.e. the sugar or salt.

Respondents mentioned increased flavour, sweetness, clarity and low viscosity as good quality indicators of monkey orange juice. Colloids such as polysaccharides are known to be responsible for the viscosity of fruit juice and cloudiness in other fruit juices such as lemon juice (Uçan et al. 2014). $S$. cocculoides and $S$. spinosa juice is viscous and the viscosity affects the appearance of the product and its overall acceptance. Processors add a significant amount of water until the juice is sufficiently liquefied. The dilution and resultant consistency depend on consumer preference, as found in the study of Bille et al. (2013), where panellists also preferred diluted juice. However, on the contrary, respondents did agree that although viscosity is reduced by dilution, the major drawback was a reduced Strychnos spp. flavour. During processing the 
separation of seed and flesh is low, giving low juice yield during processing.

Porridge is mainly prepared for and consumed by the whole family and usually introduced as a complementary food to infants from as early as four to six months. Porridge that had simmered longer lost the characteristic monkey orange flavour. Thermal treatments can inactivate enzymes that catalyse the production of volatiles as well as cause the loss of precursors of the volatile compounds (Nijhuis et al. 1998). Cooking time and ratios of addition of monkey orange juice or pulp also may have a bearing on the resultant flavour.

The most important sensory quality determinants of monkey orange fruits were colour and taste (sweetness). Fruits are picked before maturity for ripening during storage. Respondents used external visual attributes such as colour, size and surface structure to predict the taste of the fruit. Selection of this nature is, however, a subjective method (Reid 2002). There are currently no objective minimum indices for the determination of maturation at the household level in rural areas, which results in variation in fruit selection. All in all, fruit harvesting and processing conditions, and parameters, are not standardized and therefore variation in product quality are prominent for all the products we identified.

\section{Conclusion and recommendations}

Collection, processing and consumption of the monkey orange fruit are common activites in the dry and wet regions we assessed in Zimbabwe. Health benefits, value addition, market access, and education about propagation and cultivation of monkey orange fruit have an effect on proper utilization of the fruit in both regions for food and nutrition security.

Respondents in farming communities believe the fruit products, particularly porridge, have health benefits. The chemical compounds involved and mechanisms for nutritional and health benefits are unknown, as these appear to be new findings that require further scientific studies for substantiation. Exploration of strategies through scientific research for value addition and market access by small-scale fruit processing units through community cooperatives are an important contribution to curbing the challenge of food and nutrition security for households and individuals in Zimbabwe. Increasing education on the cultivation and propagation of monkey orange trees through information and planting material available at different centres in Southern Africa, such as Veld Products Research and Development, Botswana, and World Agroforestry Centre, Zimbabwe (Southampton Centre for Underutilised Crops 2006), are also important for sustainability of these indigenous fruits. We recommend putting in place a research and development program targeted at monkey orange and other underutilised fruits under the custodianship of stakeholders from government, research institutes and processors. The results of improved technologies and know-how, which will benefit women cooperatives and small-scale processors by expanding what they sell and promote and therefore their incomes, can be transferred by government extension services and NGO's.

Constraints for Strychnos spp. processing (i.e. drying rate, product splitting, flesh/seed separation, juice yield, phase separation), shelf life and sensory quality characteristics (colour, flavour, and viscosity) were increased by mainly unstandardized processing conditions and treatments. These constraints illustrate how generic some food technological problems and solutions can be, and yet how product-specific some problems and solutions are in relation to the different fruits of the same species; a concept that can be translated to various types of indigenous fruits in Southern African countries.

In scientific literature, Strychnos spp. have been labelled (amongst other indigenous fruits) as "lost fruit" (National Research Council 2008) and as neglected and underutilized species that are being lost at an extraordinary rate before they can be completely characterized, researched and promoted (Padulosi et al. 2013). Food and nutrition security is multifaceted due to its interrelated complex dimensions. To facilitate the achievement of food and nutrition security, every contribution from all disciplines is worthwhile. Therefore, as a followup to this survey, it is paramount from a food quality and design perspective to conduct experimental research to assess product quality characteristics and the contribution to nutrition of traditionally-processed products from Strychnos spp.

Acknowledgements We thank the Netherlands Fellowship Programme for financial support (grant award CF9151/2013). Also we are grateful for the assistance given by Mrs. Beauty Katsenga, Ever going Association (Mahusekwa, Marondera), Fambidzanai Permaculture, Mr. Bornface Matimba, Mr. Goodwill Moyo, community leaders, and participants in the interviews and focus groups in the study areas (Marondera, Bikita, Chimanimani and Lower Gwelo, Zimbabwe).

\section{Compliance with ethical standards}

Conflict of interest The authors declare that they have no conflict of interest.

Open Access This article is distributed under the terms of the Creative Commons Attribution 4.0 International License (http:// creativecommons.org/licenses/by/4.0/), which permits unrestricted use, distribution, and reproduction in any medium, provided you give appropriate credit to the original author(s) and the source, provide a link to the Creative Commons license, and indicate if changes were made.

\section{References}

Akinnifesi, F., Ajayi, O., Sileshi, G., Kadzere, I., \& Akinnifesi, A. (2007). Domesticating and commercializing indigenous fruit and nut tree crops for food security and income generation in sub-Saharan Africa. In Paper presented at the New Crops International Symposium, 2007 (Vol. 3, pp. 4). 
Akinnifesi, F., Kwesiga, F., Mhango, J., Mkonda, A., Chilanga, T., \& Swai, R. (2002). Domesticating priority miombo indigenous fruit trees as a promising livelihood option for small-holder farmers in southern Africa. In XXVI International Horticultural Congress: Citrus and Other Subtropical and Tropical Fruit Crops: Issues, Advances and Opportunities, 2002 (pp. 15-30).

Barry, C. S., \& Giovannoni, J. J. (2007). Ethylene and fruit ripening. Journal of Plant Growth Regulation, 26(2), 143-159.

Bello, M., Falade, O., Adewusi, S., \& Olawore, N. (2008). Studies on the chemical compositions and anti nutrients of some lesser known Nigeria fruits. African Journal of Biotechnology, 7(21), 3972-3979.

Bille, P., Shikongo-Nambabi, M., \& Cheikhyoussef, A. (2013). Value addition and processed products of three indigenous fruits in Namibia. African Journal of Food, Agriculture, Nutrition and Development, 13(1), 7192-7212.

Blandino, A., Al-Aseeri, M. E., Pandiella, S. S., Cantero, D., \& Webb, C. (2003). Cereal-based fermented foods and beverages. Food Research International, 36(6), 527-543.

Chadare, F., Hounhouigan, J., Linnemann, A., Nout, M., \& Van Boekel, M. (2008). Indigenous knowledge and processing of Adansonia digitata L. food products in Benin. Ecology of Food and Nutrition, 47(4), 338-362.

Dovie, D. B. K., Witkowski, E. T. F., \& Shackleton, C. M. (2008). Knowledge of plant resource use based on location, gender and generation. Applied Geography, 28(4), 311-322.

Ekué, M. R., Sinsin, B., Eyog-Matig, O., \& Finkeldey, R. (2010). Uses, traditional management, perception of variation and preferences in ackee (Blighia sapida KD Koenig) fruit traits in Benin: implications for domestication and conservation. Journal of Ethnobiology and Ethnomedicine, 6(12), 1-14.

Gadaga, T., Madzima, R., \& Nembaware, N. (2009). Status of micronutrient nutrition in Zimbabwe: a review. African Journal of Food, Agriculture, Nutrition and Development, 9(1), 502-522.

Gadaga, T., Mutukumira, A., Narvhus, J., \& Feresu, S. (1999). A review of traditional fermented foods and beverages of Zimbabwe. International Journal of Food Microbiology, 53(1), 1-11.

Jamnadass, R., Dawson, I., Franzel, S., Leakey, R., Mithöfer, D., Akinnifesi, F., et al. (2011). Improving livelihoods and nutrition in sub-Saharan Africa through the promotion of indigenous and exotic fruit production in smallholders' agroforestry systems: a review. International Forestry Review, 13(3), 338-354.

Kalaba, F. K., Chirwa, P. W., \& Prozesky, H. (2009). The contribution of indigenous fruit trees in sustaining rural livelihoods and conservation of natural resources. Journal of Horticulture and Forestry, 1(1), $1-6$.

Katz, H. (2006). Global surveys or multi-national surveys? On sampling for global surveys. In thoughts for the Globalization and Social Science Data Workshop. UCSB Orfalea Center for Global and International Studies, November 92006.

Legwaila, G., Mojeremane, W., Madisa, M., Mmolotsi, R., \& Rampart, M. (2011). Potential of traditional food plants in rural household food security in Botswana. Journal of Horticulture and Forestry, 3(6), 171-177.

Maga, J. A. (1987). The flavor chemistry of wood smoke. Food Reviews International, 3(1-2), 139-183.

Mapaura, A., \& Timberlake, J. (2004). A checklist of Zimbabwen vascular plants. Pretoria: South African Botany Diversity Network.

McGregor, J. (1995). Gathered produce in Zimbabwe's communal areas changing resource availability and use. Ecology of Food and Nutrition, 33(3), 163-193.

Mithöfer, D., \& Waibel, H. (2003). Income and labour productivity of collection and use of indigenous fruit tree products in Zimbabwe. Agroforestry Systems, 59(3), 295-305.

Mkonda, A., Akinnifesi, F. K., Maghembe, J. A., Swai, R., Kadzere, I., Kwesiga, F., et al. (2002). Towards domestication of 'wild orange' Strychnos cocculoides in southern Africa: a synthesis of research and development efforts. Paper presented at the southern African regional agroforestry conference, Warmbaths, South Africa, 20-24 May 2002.

Motlhanka, D. M. T., Motlhanka, P., \& Selebatso, T. (2008). Edible indigenous wild fruit plants of eastern Botswana. International Journal of Poultry Science, 7, 457-460.

Mpofu, A., Linnemann, A. R., Nout, M. J. R., Zwietering, M. H., \& Smid, E. J. (2014). Mutandabota, a food product from Zimbabwe: Processing, composition, and socioeconomic aspects. Ecology of Food and Nutrition, 53(1), 24-41.

Mwamba, C. K. (2006). Monkey orange: strychnos cocculoides crops for the future (Vol. 8). Southampton: Southampton Centre for Underutilised Crops.

National Research Council. (2008). Lost crops of Africa. Volume III: Fruits. Washington DC: The National Academies Press.

Ngadze, R. T., Linnemann, A. R., Nyanga, L. K., Fogliano, V., \& Verkerk, R. (2016). Local processing and nutritional composition of indigenous fruits: The case of monkey orange (Strychnos spp.) from southern Africa. Food Reviews International, 1-20. doi:10. 1080/87559129.2016.1149862.

Nhukarume, L., Chikwambi, Z., Muchuweti, M., \& Chipurura, B. (2010). Phenolic content and antioxidant capacities of Parinari curatelifolia, Strychnos spinosa and Adansonia digitata. Journal of Food Biochemistry, 34(s1), 207-221.

Nijhuis, H. H., Torringa, H. M., Muresan, S., Yuksel, D., Leguijt, C., \& Kloek, W. (1998). Approaches to improving the quality of dried fruit and vegetables. Trends in Food Science \& Technology, 9(1), 13-20.

Nyanga, L. K., Nout, M. J., Gadaga, T. H., Boekhout, T., \& Zwietering, M. H. (2008). Traditional processing of masau fruits (Ziziphus mauritiana) in Zimbabwe. Ecology of Food and Nutrition, 47(1), 95-107.

Osorio, C., Franco, M. S., Castaño, M. P., González-Miret, M. L., Heredia, F. J., \& Morales, A. L. (2007). Colour and flavour changes during osmotic dehydration of fruits. Innovative Food Science \& Emerging Technologies, 8(3), 353-359.

Packham, J. (1993). The value of indigenous fruit-bearing trees in miombo woodland areas of south-Central Africa. RDFN Paper 15c. https://www.odi.org/sites/odi.org.uk/files/odi-assets/ publications-opinion-files/1062.pdf. Accessed on 11 Nov 2015.

Padulosi, S., Thompson, J., Rudebjer, P., \& Bioversity International. (2013). Fighting poverty, hunger and malnutrition with neglected and underutilized species (NUS): Needs, challenges and the way forward. Rome: Bioversity International.

Rampedi, I. T., \& Olivier, J. (2013). Traditional beverages derived from wild food plant species in the Vhembe District, Limpopo Province in South Africa. Ecology of Food and Nutrition, 52(3), 203-222.

Reid, M. (2002). Maturation and maturity indices. University of California. Agriculture and Natural Resources Publication, 3311, 55-62.

Ruffo, C. K., Birnie, A., \& Tengnäs, B. (2002). Edible wild plants of Tanzania (Vol. 27): Regional land management unit/Sida.

Saka, J., Rapp, I., Akinnifesi, F., Ndolo, V., \& Mhango, J. (2007). Physicochemical and organoleptic characteristics of Uapaca kirkiana, Strychnos cocculoides, Adansonia digitata and Mangiferia indica fruit products. International Journal of Food Science \& Technology, 42(7), 836-841.

Saka, J., Swai, R., Mkonda, A., Schomburg, A., Kwesiga, F., \& Akinnifesi, F. K. (2004). Processing and utilisation of indigenous fruits of the miombo in southern Africa. In Proceedings of the Regional Agroforesty Conference on Agroforestry Impacts on Livelihoods in Southern Africa: Putting Research into Practise: held at the Aventura Resorts Warmbaths, South Africa, 20-24 May 2002, (pp. 343): World Agroforesty Centre.

Shackleton, C. M., Dzerefos, C. M., Shackleton, S. E., \& Mathabela, F. R. (2000). The use of and trade in indigenous edible fruits in the Bushbuckridge savanna region, South Africa. Ecology of Food and Nutrition, 39(3), 225-245. 
Sitrit, Y., Loison, S., Ninio, R., Dishon, E., Bar, E., Lewinsohn, E., et al. (2003). Characterization of monkey Orange (Strychnos spinosa lam.), a potential new crop for arid regions. Journal of Agricultural and Food Chemistry, 51(21), 6256-6260.

Southampton Centre for Underutilised Crops. (2006). Monkey Orange, Strychnos cocculoides, field manual for extension workers and farmers. Southampton: SCUC.

Termote, C., Van Damme, P., \& Dhed'a Djailo, B. (2010). Eating from the wild: Turumbu indigenous knowledge on Noncultivated edible plants, Tshopo District, DRCongo. Ecology of Food and Nutrition, 49(3), 173-207.

Uçan, F., Akyildiz, A., \& Ağçam, E. (2014). Effects of different enzymes and concentrations in the production of clarified lemon juice. Journal of Food Processing, 2014, 1-14.

Van Wyk, B., \& Van Wyk, P. (1997). Field guide to trees of southern Africa. Cape Town: Struik Publishers.

Vincent, V., Thomas, R.G., \& Staples, R.R. (1961). An agricultural survey of southern Rhodesia. Part 1. Agro-ecological survey. An agricultural survey of Southern Rhodesia. Part 1. Agro-ecological survey.

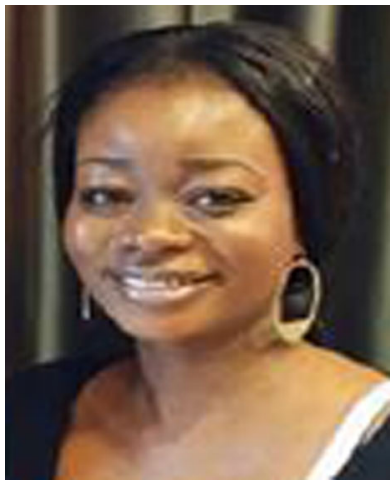

Ruth Tambudzai Ngadze is a doctoral researcher with the Food Quality and Design Group at Wageningen University in the Netherlands. Trained as a food scientist, she specialised in Food Quality for her MSc. Her interest is in promoting the utilization of neglected and underutilized fruits with the collaboration of local universities in Zimbabwe (Chinhoyi University of Technology and the University of Zimbabwe). Her current research aims at improving local processing for the design of functional products that can be best applied and utilized by local communities in Southern Africa, using locally available indigenous fruits.

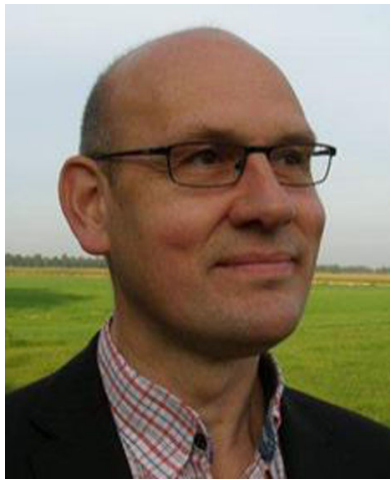

Ruud Verkerk obtained his BSc on general microbiology and received his $\mathrm{PhD}$ in food technology from Wageningen University, The Netherlands. He has worked his whole career in different positions at Wageningen University, where he is now an associate professor in the Food Quality and Design group. His main research focus is on secondary plant metabolites (phytochemicals) in food supply chains with specific emphasis on processing. He specializes in the role of the food matrix in the behaviour of nutrients and phytochemicals in relation to processing of fruits and vegetables.

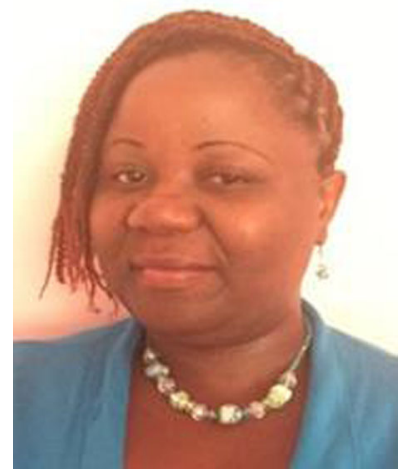

Loveness K. Nyanga is a senior lecturer and researcher at the Institute of Food, Nutrition and Family Sciences, University of Zimbabwe. She is the chairperson of Nutrition Action Zimbabwe, a local NGO in Zimbabwe. She holds a $\mathrm{PhD}$ in Food Science from Wageningen University, The Netherlands. Her research areas include traditional and indigenous foods, food safety, food and nutrition security and small scale agro-processing technologies.

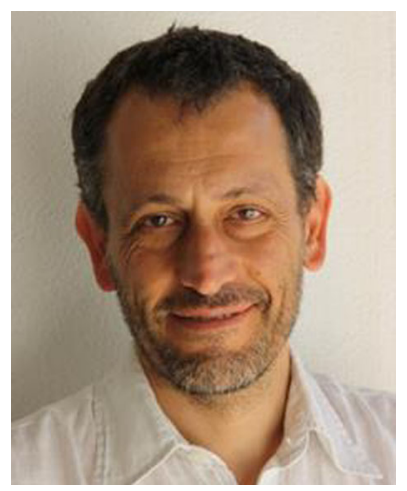

Vincenzo Fogliano graduated in Chemistry at the University of Rome and received a $\mathrm{PhD}$ in Food Science at Corvinus University of Budapest. He held various positions in Biochemistry and Food Chemistry at the universities of Rome and Naples. In 2013 he became Professor and chair of the Food Quality Design Group at the University of Wageningen, The Netherlands. His activity is on the Maillard reaction, the design of functional food containing dietary fibre, proteins and phytochemicals from different sources. He acted as coordinator of FP7 EU projects, COST action and strategic national cluster projects. Vincenzo was President of the International Maillard Reaction Society up to 2012 and is a member of the advisory board of ILSI Europe. He is the author of more than 250 publications (h index of 46), being among the world's highly cited scientists according to the ISI Thompson list (www.highlycited.com).

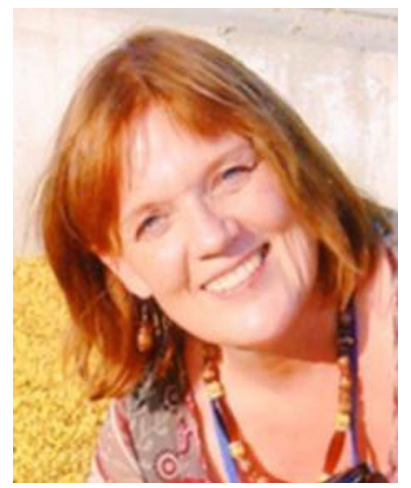

Anita Linnemann obtained a double Masters degree from Wageningen University in Tropical Agriculture and Food Technology. She completed her PhD thesis, entitled Ecophysiology of bambara groundnut (Vigna subterranea (L.) Verdc.), and has been a staff member of the Food Quality and Design group of Wageningen University since 1995. Her expertise is in consumer-orientated food product development with special attention to sustainability issues. Her work in education and research is characterised by an interand transdisciplinary approach and the integration of natural and social sciences. At present Anita is supervising $\mathrm{PhD}$ students from Benin, Kenya, Zambia and Zimbabwe, who are working on foods from, amongst others, cashew, shea, dye sorghum, banana, baobab, bambara groundnut and monkey orange. 